Journal of Electronic Resources Librarianship, 20: 169-177, 2008

Copyright $\odot 2008$ The Haworth Press

ISSN 1941-126X print / 1941-1278 online

DOI: $10.1080 / 19411260802412877$

\title{
CLEAR AS GLASS: A COMBINED LIST OF PRINT AND ELECTRONIC JOURNALS IN THE KNOWLEDGE BASE
}

\author{
M. Sara Lowe
}

The non-standard practice at Cowles Library at Drake University has been to display electronic journals and some print journals in the Knowledge Base while simultaneously listing print journals and some electronic journals in the online public access catalog (OPAC). The result was a system that made it difficult for patrons to determine our journal holdings while not providing any benefits to our technical services department.

Whether or not to display electronic holdings with print holdings in the OPAC is a frequently debated question. For institutions that do not have the cataloging or technical services staff to keep up with constantly changing electronic holdings, a better question is whether or not to add the print holdings to the list of electronic resources (a knowledge base). The library has listed all journal holdings (print and electronic) in the knowledge base. At the same time, Cowles Library reevaluated its procedure regarding the display of electronic journals in the OPAC. By addressing these issues, Cowles Library hopes that it has implemented changes that will better serve librarians, faculty, and students. This article discusses the procedure changes implemented primarily to aid users but also to streamline and standardize workflows for staff.

Keywords: Electronic journals, print journals, knowledge base, catalog, OPAC

Cowles Library, like many libraries, implemented electronic journal procedures haphazardly. As the number of electronic resources began to increase exponentially (aptly described by Jones, 2002 as "e-creep"), it became harder to keep track of the resources or execute the procedures. Thus,

M. Sara Lowe, MLS, MA is the Electronic Resources Specialist at Drake University, Des Moines, Iowa (E-mail: sara.lowe@drake.edu).

Acknowledgment: Special thanks to Cong Liu for all her hard work in manipulating massive Excel files of dead serial titles to help make this project a reality. 
electronic journals and active print journals were listed in the Knowledge Base (in this case, Gold Rush), and at the same time, all print journals and some electronic journals were listed in the OPAC. Users of the library were presented with an opaque process where, in order to find journal holdings, they had to search both the OPAC and the e-journal Knowledge Base.

It was obvious that this approach was doing a disservice to our patrons. Reference librarians reported numerous questions that were simply "Do we have this journal?" Library instruction classes had to devote extra time to showing users how to find all of the library's journal holdings. In addition, the inter-library loan (ILL) office received daily requests for articles where the library did own the article (either in print or electronic format). Thus, not only were users aggravated but the staff was forced to do extra work just to remove some of the ambiguity of the system. The most frustrating aspect was that none of this really did any good, as users (and staff) would forget about the dual listings and need to be constantly reminded to check both places.

In theory, an institution's OPAC should inform patrons of all available holdings at the library, regardless of format. With the ascendancy of electronic resources, whether or not to (or how to) include electronic holdings with the print holdings has been problematic with every library approaching the problem in a different way (see Literature Review). Numerous publications debate displaying electronic holdings in the OPAC (see Literature Review). However, for libraries who do not have enough cataloging or technical services staff to import and maintain machine readable cataloging (MARC) records in the (relatively static) OPAC, this is not a viable option. Nor does listing the electronic holdings in the OPAC address the needs of users who expect to be able to link from a search engine or database to an article (Coker, 2007). A more feasible option for both users and staff is displaying the print holdings in the Knowledge Base whereby electronic journals are primarily updated by the provider (Gold Rush) and the library is responsible only for maintaining the print holdings. Cowles Library at Drake University recently implemented this change.

While this project was initiated from a usability standpoint, this article also discusses the internal workflow changes necessary to implement the change. This entire process (both internally and externally) operates on the principle of least effort, whereby "each individual will adopt a course of action that will involve the expenditure of the probably least average of his work" (Zipf, 1949). Although this project was implemented through Gold Rush, it would work with any electronic resources management (ERM) or A-Z Knowledge Base system (Serials Solutions, SFX, etc.) 


\section{LITERATURE REVIEW}

While this project originally addressed this issue from the users' point of view, staff workflows were also a deciding factor in whether or not to combine the holdings. A large amount of literature on this subject exists with every library approaching the problem in a different way.

Regarding usability, much of the literature supports the library's procedure changes. Coker (2007) states that users reach article-level access from search engines or from databases or library Web sites. While sometimes starting from an OPAC, with the continued growth of digital object identifiers and OpenURL technology, most users are coming from someplace else (such as Google Scholar). Ferguson, Collins, \& Grogg (2006) conducted a survey and found that, when given the choice between the OPAC or a Web list, users showed a clear preference for the Web list as the primary way to access materials. Yi and Herlihy (2007) conducted a longterm study and found that the implementation of an OpenURL resolver has directly contributed to increased database usage. They also noted changing patron research practices where users prefer search engines and are more comfortable with Google-type searching.

From a workflow standpoint, copious literature exists on whether or not to display electronic resources in the OPAC or through a Web list or Knowledge Base. If the OPAC is used, the next question is whether to list the electronic and print holdings in single or multiple records. Anderson (1999); Calhoun and Kara (2000); Chen et al. (2004); Chrzastowski (1999); Collins (2005); Davis (2007); Ewing (2005); Ferguson et al. (2006); Jones (2002); Leatham (2005); McCracken (2007); McMullen and Wilmott (2005); Murphy (2002); Simpson, Lundgren, \& Barr, (2007); and Stalberg (2001) all address this issue in some form, to name just a few.

Most come to the same conclusions as Cowles Library (see, for example, McCracken [2007] and Murphy [2002], who both do an excellent job stating the pros and cons of listing electronic resources in the OPAC). While the OPAC is the traditional means of displaying library holdings, it is not nimble enough (nor is there ever enough staff) to display electronic holdings in an effective way. URLs change (see Strader and Hamill [2007] for an entire article based on the weeding and maintenance of URLs in the OPAC), proxy servers change, aggregators drop and add titles, and so on, all of which combine to create an environment where staff are running to stay in place and users are not presented with the most current electronic information. Comments given to O'Hara in her 2007 survey revealed that librarians are struggling to find ways to catalog and maintain electronic journal records in the OPAC.

What is interesting is that even when recognizing the inherent limitations of the OPAC; the literature still addresses how to overcome 
these problems to get the records into the catalog. O'Hara (2007, p. 123) found that $92 \%$ of libraries cataloged electronic journals. McCracken (2007, p. 271) is not alone when she writes, "Online resources should be cataloged along with the other materials the library holds so that users have one place where they can search the entire collection." Although Stalberg (2001) states, "We generally feel we are treading water to keep up with the newest technology" (p. 19), his library still decided to give title-level access to electronic journals in their OPAC because "we pay for them all" (p. 20). Chen et al. (2004) found in their literature review that the general consensus of librarians was toward the OPAC as the primary means of accessing electronic content. Even though Calhoun and Kara (2002) state, "Conventional cataloging could solve the problem of aggregations, but most of today's resource-strapped cataloging departments do not have the means to do it," they then go on to discuss the pros and cons of the single versus multiple record OPAC approach. Why librarians feel a loyalty to the OPAC even when it is not the right tool for the job-and many libraries recognize this in practice by using both the OPAC and Web lists-is beyond the scope of this article.

Holman (2005), detailing Ex Libris SFX ${ }^{\circledR}$ implementation at UW-La Crosse, and Chrzastowski (1999), stating the "principle of least effort," advocate dynamic web list access over the OPAC. The O'Hara (2007) and Chen et al. (2004) surveys would imply that more libraries are employing the A-Z Knowledge Base list than is reported in the literature. Chen's survey showed $94 \%$ used both the OPAC and Web lists to provide access to electronic journals, while O'Hara found that $90 \%$ of libraries surveyed provided access to electronic journals through a list or database not the OPAC (p. 125). When this number is compared to the $92 \%$ stated above who catalog electronic journals, it argues strongly that many libraries are pursuing a blended approach, which is what Cowles Library elected to do as well.

\section{Background}

Drake University is a smaller liberal arts college with a full-time enrollment of approximately 4,600 students. Drake University has reputable graduate and professional programs in law, pharmacy, education, and business.

Cowles Library is one of two libraries on campus, the other being the Law Library. Although both libraries share the same OPAC, electronic journal displays are kept separate due to restrictions on many Law Library database subscriptions. Cowles Library has approximately 430,000 monographs; 1,900 serials; 35,000 unique e-journals (including both individual subscriptions and aggregators); and 41,000 e-books. 


\section{Previous Practice}

Until late 2007, Drake University did not have a designated electronic resources employee. Rather, different tasks were performed by a variety of employees. When Drake University subscribed to only a handful of electronic resources, this approach worked fine. However, as the number of resources grew, employees' abilities to handle their designated area (in addition to their regular work load) began to slip. Also, procedures that had been implemented years ago were no longer sufficient to address the large number of resources now available electronically. With the hiring of an electronic resources employee, Drake University recognized that more needed to be done to adequately deal with electronic resources.

Although never a written policy-rather a set of informal practices implemented over time-the system for displaying electronic and print resources worked as follows:

1. The Knowledge Base contained all electronic journals and current print journals.

2. All print journals (current, defunct and canceled) were listed in the OPAC.

3. Some electronic journals were cataloged in the OPAC in records separate from their print counterparts (if there was a print version). These were mainly journals from perpetual access collections such as JSTOR, although not all such holdings were in the OPAC.

4. A small minority of electronic titles were cataloged in the same record as the print version.

5. Journal holdings from aggregated databases were not listed in the OPAC.

\section{Effect of Procedures on Users}

As stated earlier, users of the library were presented with an opaque process where, in order to find journal holdings, they had to search both the OPAC and the Knowledge Base (a problem documented by Calhoun and Kara [2000] in reference to aggregator databases). Because of the hodge-podge combination of some electronic holdings in the OPAC and some print holdings in the Knowledge Base, users were not aware that they had to search both places to determine holdings. Reference librarians would frequently have to answer the question "Do you have this journal?" Library information-literacy classes had to specifically stress our journal holdings procedure because the process was not intuitive.

A recent usability study at the library highlighted the problem when it was demonstrated that students had great difficulty determining where to go to determine journal holdings. For example, when asked to find a 
journal, one-third of students went to the OPAC but could not find our online holdings. Two-thirds of students started from the Knowledge Base but could not discern our print holdings.

Even seasoned library patrons and librarians, who were aware of the separated holdings, did not always remember to check both the OPAC and the Knowledge Base for the complete list of holdings. This reinforces what Serotkin, Fitzgerald, \& Balough (2005) found in their usability study where some electronic journals were located in a separate place from others. Users stated that "unless someone 'reminded' them, they simply forgot that the journals were available" (p. 507).

Effect of Procedures on Staff and Workflows

The haphazard procedures were also a hindrance to staff and workflows. Information literacy classes had to emphasize the procedure. This arrangement also caused excess work for the understaffed ILL department as they would regularly find that Cowles Library did indeed own the requested article, but the patron didn't know to check both the OPAC and the Knowledge Base. In addition, without a written policy and rigorous follow-up, as the number of e-resources exploded, the informal procedures were being adhered to less and less.

\section{Procedure Change}

With the limited resources (both financial and personnel) available to Cowles Library, the following procedure changes were proposed to and approved by the Electronic Resources Selection Committee (whose scope is much wider than the name implies):

\section{Add all print journals (active, defunct and canceled) to the Knowledge Base.}

2. Remove e-journal holdings from the OPAC.

\section{Point 1: Add All Print Journals to the Knowledge Base}

The reasons for this change are obvious when the logistics are considered. Cowles Library subscribes to Gold Rush which provides a Knowledge Base (A-Z electronic journal list), Article Linker, and ERM. Unfortunately, Cowles Library has a rather small technical services department, with only one full-time cataloger. To ask this employee to keep track of 35,000 electronic journals in the OPAC is not possible. However, it is possible to link the static OPAC through the medium of the dynamic Knowledge Base.

This was the only feasible route. Fortunately, active print subscriptions were already displayed in the Knowledge Base. The problem lay in the addition of all the defunct or canceled print subscriptions. Gold Rush 
does not charge extra to list local holdings, so there would be no fiscal repercussions from adding thousands of titles to the Knowledge Base. Regarding usability, it is the library's contention (discussed by Coker, 2007) that most users (especially students) are not searching for a specific journal; rather, they are starting in the databases (or Google), searching on topics, and then determining library holdings through an OpenURL article linker. The more complete the content in the Knowledge Base, the more accurate the article linker will be. Although patrons might have to come in to the library for a hard copy of the article (rather than an electronic copy), at least they will know it is available.

\section{Point 2: Remove E-Journal Holdings from the OPAC}

It was agreed upon by the Electronic Resources Selection Committee that all electronic journal records would be removed from the OPAC. There was never a standard policy, and both the single and multiple record approaches were used intermittently. Among the multiple records, many electronic journals were cataloged differently than the print version, and an OPAC search on a journal title did not guarantee that both print and electronic holdings would be retrieved.

\section{Implementation and Initial Results}

The procedure changes were approved in January 2008. The electronic resources specialist and a student employee have compiled a complete list of print holdings to upload to the Knowledge Base. The major hurdle to this process was the creation of a list of defunct or canceled serials, which was tedious and time-consuming. This process is now two-thirds complete with those titles listed in the Knowledge Base. The removal of e-journal records from the catalog has been slower in coming owing to limited human resources.

Adding the print holdings to the Knowledge Base will greatly improve accessibility. Reference librarians and the ILL department have already noticed fewer questions regarding our holdings and fewer requests for materials the library already owns. In the Knowledge Base, local holdings link to the OPAC so the only time it will need to be changed is if the library cancels a subscription (add the subscription end date) or weeds the print holdings (remove the record entirely). Coincidentally, the library Web site is being redesigned, and the combined journal list has been integrated into the design. Users will now be routed to "Books" (e.g., the OPAC) or "Journals" (e.g., the Knowledge Base of combined list of print and electronic journals).

The situation is not as clear regarding the cataloging changes, owing to our purchasing procedures. The acquisitions department has to have a 
record in the catalog to which it attaches the purchase order. By confining the OPAC to print serials only, what will the library do with individual electronic journal subscriptions which need a record in the catalog to attach the purchase order? The library has decided that when the situation arises, a record will be added to the OPAC, but it will be "shadowed" so that patrons won't see it but the information is still available to the acquisitions department.

\section{CONCLUSION}

By revising the procedures for displaying print and electronic serials, Cowles Library believes that it has solved many of the usability problems that were occurring owing to the explosion of electronic resources without a corresponding review of procedures and workflows to make sure they were meeting patron and staff needs. The primary lesson learned from this experience is that whatever policies are implemented, they must be reviewed regularly to determine whether they are still effective. McCracken (2007) states, "The current hybrid approach to provide traditional cataloged records and A-Z lists of aggregator databases and electronic journals on the library Web site seems an interim approach effective only in the short-term" (p. 261). The number of electronic resources are constantly growing and the means to access them evolving.

As OpenURL technology continues to progress, and when the most basic Knowledge Base is almost a necessity to any library with a reasonable number of electronic resources, the problem will be solved for libraries. The Anglo-American Cataloging Rules (AACR) were adopted in 1967. The days of traditional cataloging procedures where it was feasible to list every item in the OPAC are gone. The rapid growth of technology will ensure that the time between the implementation of new cataloging and tracking procedures will become less and less. It is almost a certainty that the combined list of print and electronic journals will not serve Cowles Library for the length of time that the AACR has. If the library does not adapt to meet these changes, it will become extinct.

\section{BIBLIOGRAPHY}

Anderson, B. (1999). Web lists or OPACs: Can we have our cake and eat it, too? Library Computing, 18(4), 312-316.

Calhoun, K., \& Kara, B. (2000). Aggregation or aggravation? Optimizing access to full-text journals. ALCTS Newsletter (Online), 11(1). Retrieved http:// archive.ala.org/alcts/alcts_news/v11n1/gateway_pap15.html; Retrieved May 23, 2008 . 
Chen, X., et al. (2004). E-Resource cataloging practices: A survey of academic libraries and consortia. Serials Librarian, 47(1/2), 153-179.

Chrzastowski, T. (1999). E-journal access: The online catalog (856 field), web lists, and "The principle of least effort." Library Computing, 18(4), 317-322.

Coker, G. (2007). Usability in emerging E-content environments. Information Services \& Use, 27, 179-184.

Collins, M. (2005). The effects of E-journal management tools and services on serials cataloging. Serials Review, 31(4), 291-297.

Cowles Library Databases. http://www.lib.drake.edu/site/databases/; Retrieved May 23, 2008.

Davis, S. (2007). Climbing the mountain: Choosing the best path for serials record management. Serials Librarian, 52(3/4), 335-339.

Electronic Resources in Libraries-Listserv. Archives of ERIL-L@LISTSERV. BINGHAMTON.EDU; Retrieved May 23, 2008. http://listserv.binghamton. edu/archives/eril-l.html.

Ewing, C. (2005). Creating a Web-accessible combined print and electronic journal listing. Journal of Electronic Resources in Medical Libraries, 2(2), 13-23.

Ferguson, C. L., Collins, M. D. D., \& Grogg, J. E. (2006). Finding the perfect ejournal access solution. . . the hard way. Technical Services Quarterly, 23(4), 27-50.

Holman, J. S. (2005). Can SFX replace your homegrown periodicals holding list? How the University of Wisconsin-La Crosse made the transition. Serials Librarian, 47(4), 79-88.

O’Hara, L. H. (2007). Providing access to electronic journals in academic libraries: A general survey. Serials Librarian, 51(3/4), 119-128.

Jones, W. (2002). How to do it not badly. Serials Librarian, 43(2), 17-20.

Leathem, C. A. (2005). Choices in cataloging electronic journals. The Acquisitions Librarian, 17(33/34), 73-83.

McCraken, E. (2007). Description of and access to electronic resources (ER): Transitioning into the digital age. Collection Management, 32(3/4), 259-275.

McMullen, K., \& Wilmott, D. (2005). Taming the e-journal jungle: The University of South Carolina's experience with TDNet. The Serials Librarian, 47(4), 35-42.

Murphy, A. (2002). Cataloging electronic journals: A practical guide. College \& Undergraduate Libraries, 9(1), 81-95.

Serotkin, P. B., Fitzgerald, P. I., \& Balough, S. A. (2005). If we build it, will they come? Electronic journals acceptance and usage patterns. Portal: Libraries and the Academy, 5(4), 497-512.

Simpson, B., Lundgren, J., \& Barr, T. (2007). Linking print and electronic books: One approach. Library Resources \& Technical Services, 51(2), 146-152.

Stalberg, E. (2001). Bibliographic access to titles in aggregator databases: One library's experience. Serials Librarian, 39(4), 19-24.

Strader, C. R. \& Hamill, F. D. (2007). Rotten but not forgotten: Weeding and maintenance of URLs for electronic resources in The Ohio State University online catalog. Serials Librarian, 53(1/2), 163-177.

Yi, H., \& Herlihy, C. S. (2007). Assessment of the impact of an open-URL link resolver. New Library World, 108(7/8), 317-331.

Zipf, G. K. (1949). Human behavior and the principle of least effort: An introduction to human ecology. New York: Addison-Wesley. 